\section{Awards in Anthropology}

The Wellcome Gold Medal for research in anthropology for 1936 has been awarded by the Council of the Royal Anthropological Institute to Dr. Charles Kingsley Meek for an essay entitled "Law and Authority in a Nigerian Tribe". In accordance with the terms of award laid down when the medal was instituted by the late Sir Henry Wellcome, the subject of research is the application of the science of anthropology to the problems of administration among backward peoples. Dr. Meek was formerly an officer of the Nigerian administrative service, and has for long been known as the foremost authority on the native tribes of Northern Nigeria. $\mathrm{He}$ is the author of a number of works in which the ethnography of the territory has received detailed treatment. The Council of the Institute has also awarded the Rivers Memorial Medal to Dr. Edward Evan EvansPritchard. This medal is awarded in recognition of recent meritorious field work. On this occasion, the Council has had before it the results of Dr. EvansPritchard's work in the Anglo-Egyptian Sudan and in Kenya since 1926. Dr. Evans-Pritchard, who was educated at Exeter College, Oxford, and studied anthropology at the London School of Economics, was appointed in 1926 by the Sudan Government to carry on the ethnographical survey of the tribes of the Anglo-Egyptian Sudan which had been initiated by Prof. C. G. Seligman, and later for a time was professor of anthropology in the University of Cairo. $\mathrm{He}$ has also acted as honorary secretary of the Royal Anthropological Institute. From time to time, the earlier results of his researches have been published in Sudan Notes and Queries and in the Journal of the Anthropological Institute. His further studies have appeared recently in a work on witchcraft among the Azande, which has been pronounced by those most competent to judge to be one of the outstanding works of recent years in anthropology. Dr. EvansPritchard is now engaged in preparing a further work on the religion and social organization of the Azande.

\section{Wool Research in Australia}

TrE decision of the Australian Government last year, at the instance of pastoralists, to impose a levy on wool production, has been followed by the appointment of a Wool Board, with six members representing the industry and one the Commonwealth Government. The levy may be up to $6 d$. per bale, and the funds are to be used for (i) scientific research and (ii) publicity for the benefit of all sides of the wool industry. The Board has recently determined upon its expenditure under the first heading during the next financial year, and its decisions should result in marked stimulation of scientific work, particularly of that being carried on under the auspices of the Council for Scientific and Industrial Research. $£ 2,750$ has been granted for extensions to the Council's Nutrition Laboratory in Adelaide ; $£ 1,600$ for sheep blowfly investigations at Canberra and Sydney; $£ 900$ for provision of additional accommodation at the McMaster Laboratory in Sydney; $£ 730$ per annum for three years for parasitological field work ; $£ 100$ capital and $£ 370$ per annum for three years for further study of external parasites of sheep; $£ 500$ for the Council's field station at St. Mary's, some twenty miles from Sydney; $£ 484$ for three years for increased staff for fertility studies; and minor amounts for further investigations into toxæmic jaundice, foot-rot and ophthalmia in sheep.

IN addition to these grants, the Australian Wool Board has agreed to support a project for establishing in South Queensland a field station for large-scale investigations of sheep problems, including tests of methods for mitigating the blowfly pest. The Queensland Government has granted the Commonwealth Council a thirty years lease, at a peppercorn rental, of an area of 40,000 acres in the Cunnamulla district. Towards the capital expenditure on buildings, fencing, etc., that will be necessary, the Board has allotted $£ 10,000$ in the first year and $£ 7,500$ in the second. The establishment of this station is cordially approved by wool-growers throughout Australia, and it should serve as an effective additional link between the practical growers and the research workers in the city laboratories.

\section{Arms for the British Association}

The British Association has received a grant of armorial bearings from the College of Arms, the necessary fees being met by gifts from an anonymous donor and from ex-presidents of the Association.

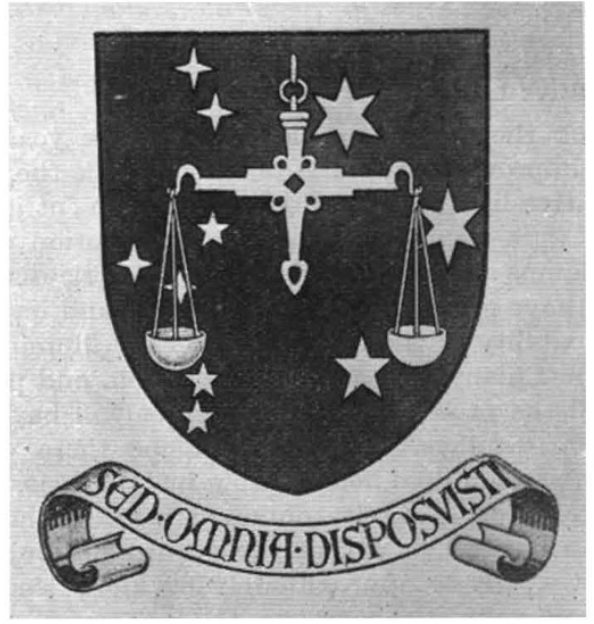

The shield is described as azure ten stars, two of six, four of five, and four of four points argent, representing the constellation of Libra; over all a balance or. The motto, Sed omnia disposuisti, is taken from "Wisdom of Solomon", ii, 20 (But Thou hast ordered all things in measure and number and weight).

\section{University of Sheffield and Sir Robert Hadfield}

In NATURE of October 10, 1936 (p. 610), reference was made to the appeal for $£ 250,000$ being made by the University of Sheffield for urgently needed extensions and for endowments. The first list of 